\title{
Carbon-13 enrichment in benthic compared to planktonic algae: foodweb implications
}

\author{
R. L. France \\ Department of Biology, McGill University, 1205 Ave. Dr. Penfield, Montreal, Quebec, Canada H3A 1B1
}

\begin{abstract}
Previous work has shown freshwater macrophytes from lake littoral zones to be ${ }^{13} \mathrm{C}$-enriched compared to the same species collected from fast moving rivers. It is thought that carbon fixation in aquatic plants having thicker, stagnant boundary layers, such as that which occurs within low turbulence lentic systems, will result in more positive $\delta^{13} \mathrm{C}$ values due to greater diffusion resistance and subsequent assimilation of otherwise normally discriminated ${ }^{13} \mathrm{C}$. The present study confirms this hypothesis by examining 876 algal $\delta^{13} \mathrm{C}$ values collected from the literature. The average $\delta^{13} \mathrm{C}$ value for benthic algae in lakes was $-26 \%$, whereas that for riverine benthic algae was $-29 \%$. The greater water turbulence to which planktonic algae are exposed is known to dramatically reduce boundary layer thickness and was found to cause even more severe ${ }^{13} \mathrm{C}$ depletion, resulting in an average value of $-32 \%$. This same effect also operates in coastal environments where the average $\delta^{13} \mathrm{C}$ value for marine phytoplankton was $-22 \%$ compared to $-17 \%$ for marine benthic algae. When comparisons were made on an individual study basis, differences of $10 \%$ or greater in $\delta^{13} \mathrm{C}$ were observed between planktonic and benthic algae in both oceans and lakes. These algal differences in $\delta^{13} \mathrm{C}$ were found to be substantial enough to be reflected in the $\delta^{13} \mathrm{C}$ values of consumers in marine coastal environments.
\end{abstract}

KEY WORDS: $\delta^{13} \mathrm{C} \cdot$ Marine $\cdot$ Freshwater $\cdot$ Benthic and planktonic algae

Ratios of stable carbon isotopes in aquatic plants such as marine macroalgae (Fry \& Sherr 1984) and freshwater angiosperm macrophytes (Keeley \& Sandquist 1992) are considerably more variable than are those of terrestrial plants. One possible reason that has been advanced to account for at least some of this variability is the major photosynthetic difference that exists between aquatic and terrestrial plants due to the diffusional resistance to $\mathrm{CO}_{2}$ being 4 orders of magnitude greater in water than it is in air (Keeley \& Sandquist 1992). The greater viscosity of water therefore creates a stagnant boundary layer around aquatic plants (up to $150 \mu \mathrm{m}$ in thickness for macrophytes), restricting the rate of $\mathrm{CO}_{2}$ or $\mathrm{HCO}_{3}^{-}$diffusion, and thereby representing a major rate-limiting step in photosynthesis (Smith \& Walker 1980). In effect, the carbon pool for aquatic plants is finite, producing a biochemical disequilibrium in isotopic discrimination between the stagnant boundary layer of progressively depleted carbon and the bulk solution of constantly mixed carbon (Andrews \& Abel 1970, Smith \& Walker 1980). Therefore, the fixation of carbon in aquatic plants with well-defined boundary layers leads to an entrapment of otherwise normally discriminated (expelled) ${ }^{13} \mathrm{C}$. The result is a more positive ${ }^{13} \mathrm{C} /{ }^{12} \mathrm{C}$ ratio and subsequently higher $\delta^{13} \mathrm{C}$ signature of plant tissue (Keeley \& Sandquist 1992).

Given the importance of diffusion resistance to the degree of isotopic discrimination, the $\delta^{13} \mathrm{C}$ signatures of aquatic plants should be influenced by the extent of mixing between inorganic carbon in boundary layers and that of the bulk solution. Indeed, Osmond et al. (1981) determined that freshwater macrophytes from low turbulence sites at the shores of lakes had more positive $\delta^{13} \mathrm{C}$ values than those of the same species collected from fast moving water. Similarly, increased stand productivity and inferred decreased water circulation may have been responsible for the higher $\delta^{13} \mathrm{C}$ observed within certain kelp beds (Simenstad et al. 1993) due to alterations in boundary layer thickness (cf. Wheeler 1980). Finally, laboratory experiments have shown that $\delta^{13} \mathrm{C}$ values for individual algal species were decreased under conditions of high turbulence caused by rapid aeration (Degens et al. 1968a).

Because benthic algae are known to have diffusive boundary layers of over $1 \mathrm{~mm}$ in thickness (Jørgensen \& Revsbech 1985, Riber \& Wetzel 1987), their use for investigating the effects of water turbulence on plant $\delta^{13} \mathrm{C}$ is appealing. The purpose of the present study was, therefore, to collate existing literature data on $\delta^{13} \mathrm{C}$ for marine and freshwater benthic algae and to 
compare these values with those determined for planktonic algae. Phytoplankton, exposed to highly turbulent conditions, are expected to have residual diffusive boundary layers in the order of only $10 \mu \mathrm{m}$ thickness (Dainty in Smith \& Walker 1980) and, as such, may therefore represent a $\delta^{13} \mathrm{C}$ minimum for aquatic plants.

Localized differences between regions can result in ambiguity as to the widespread generality of observed isotopic patterns (Fry \& Sherr 1984). Because, on a global scale, a considerable variability exists in the $\delta^{13} \mathrm{C}$ values of both benthic and planktonic marine algae in relation to environmental differences in light and temperature, as well as to algal differences in photosynthesis mechanisms, rates of primary production and species composition (e.g. Sackett et al. 1965, Deuser 1970, Raven 1970, Fontugne \& Duplessy 1978. Fageneli et al. 1986, Wienke \& Fisher 1990, Fry \& Wainright 1991), it is difficult to reach consensus about whether benthic-planktonic differences exist in carbon pathways on the basis of individual studies only. This occurs because the true $\delta^{13} \mathrm{C}$ variability of autotrophs may go unrecognized due to either inadequate sampling or presentation of data as mean values only. The objective of the present secondary analysis of literature results is to examine the complete range of $\delta^{13} \mathrm{C}$ which has been recorded for benthic and planktonic algae and consumers collected from both littoral and pelagic sites on a global basis. Comparing the $\delta^{13} \mathrm{C}$ frequency distributions originating from these 2 habitats should provide insight as to whether carbon flow in coastal regions is either tightly coupled or separated between benthic and planktonic sources.

Stable carbon isotope values were obtained for 876 algal samples directly from tables and from figures with use of a digitizing reader. Values for benthic algae represent periphyton (epipelic and epilithic forms), epiphyton, and haptobenthos from marine and both lotic and lentic freshwaters. Values for planktonic algae are particulate organic matter from the pelagic zones of oceans or lakes. Data sources are: Parker (1964), Sackett et al. (1965), Degens et al. (1968b), Deuser (1970), Haines (1976), Haines \& Montague (1979), Rau (1980), Fry et al. (1982, 1983), Macko et al. (1982), McConnaughey \& McRoy (1982), Rounick et al. (1982), Hughes \& Sherr (1983), LaZerte (1983), Schwinghamer et al. (1983), Fry \& Sherr (1984), Gearing et al. (1984), Rodelli et al. (1984), Estep \& Vigg (1985), Nichols et al. (1985), Rounick \& Hicks (1985), Simenstad \& Wissmar (1985), Araujo-Lima et al. (1986), Winterbourn et al. (1986), Peterson \& Howarth (1987), Wada et al. (1987), Yoshioka et al. (1988, 1989), Bunn et al. (1989), Kline et al. (1990), Rau et al. (1990), Sullivan \& Moncreiff (1990), Takahashi et al. (1990a, b), Fry (1991), Hesslein et al. (1991), Shoto-Douglas et al. (1991), Hamilton et al. (1992), Hobson \& Welch (1992),
Rosenfield \& Roff (1992), Bunn \& Boon (1993), Forsberg et al. (1993), Junger \& Planas (1993), Kling (1994), and Milhuc \& Toetz (1994).

If diffusion resistance is important to ${ }^{13} \mathrm{C}$ discrimination, then algal $\delta^{13} \mathrm{C}$ should not only reflect the ultimate source of carbon for photosynthesis but also distinguish between different microenvironments within systems as well. In marine coastal areas (Fig. 1), benthic algae $[-17 \pm 4(\mathrm{SD}) \% \mathrm{c}]$ are on average ${ }^{13} \mathrm{C}$-enriched by about $5 \%$ compared to planktonic algae $(-22 \pm$ $3 \%$ ). In freshwaters (Fig, 2), benthic algae exhibited $\delta^{13} \mathrm{C}$ values of $-26 \pm 3 \%$, phytoplankton of $-32 \pm 3 \%$, an average difference of about $6 \%$. Further, as would be expected if the $\delta^{13} \mathrm{C}$ difference between benthic and planktonic algae is due to water turbulence effects on boundary layer diffusion resistance, riverine benthic algae have $\delta^{13} \mathrm{C}$ values $(-29 \pm 4 \%$ intermediate between the 2 hydrodynamic endpoints. On an individ-
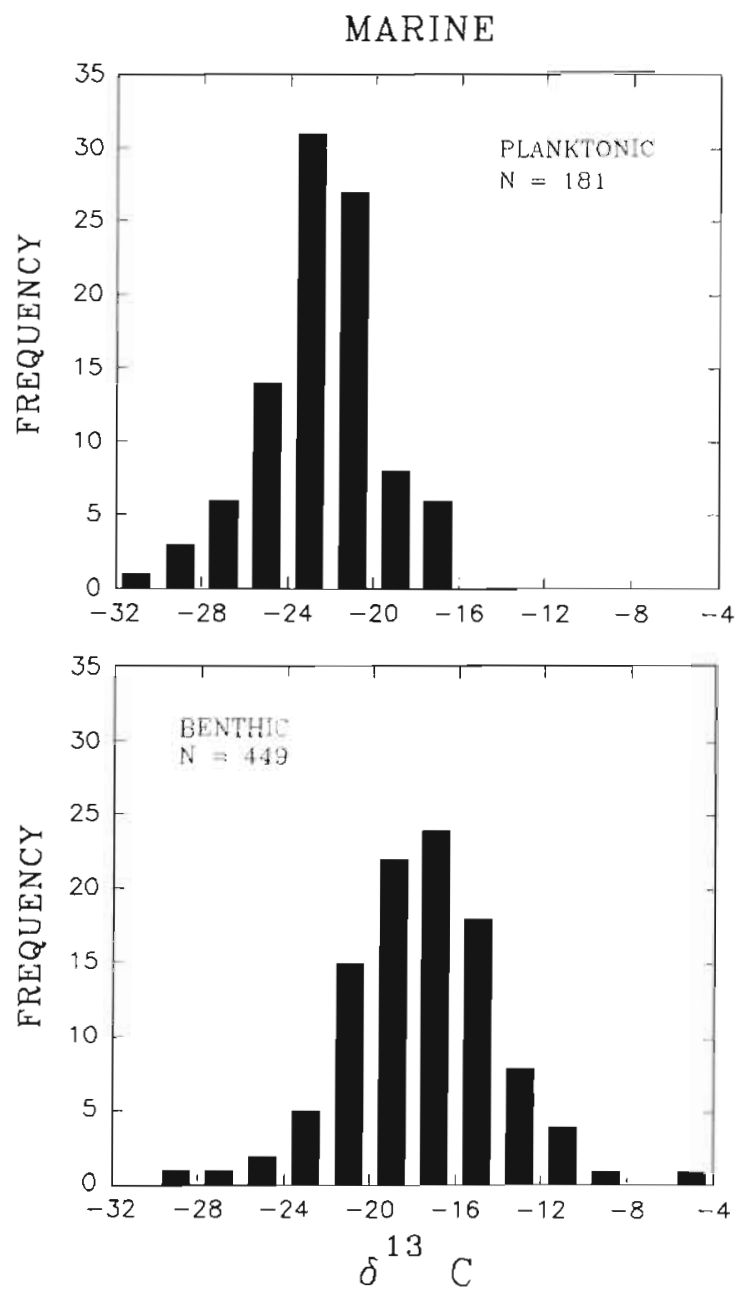

Fig. 1 Percentage frequency distributions of stable carbon isotope ratios for benthic and planktonic algae in marine environments 

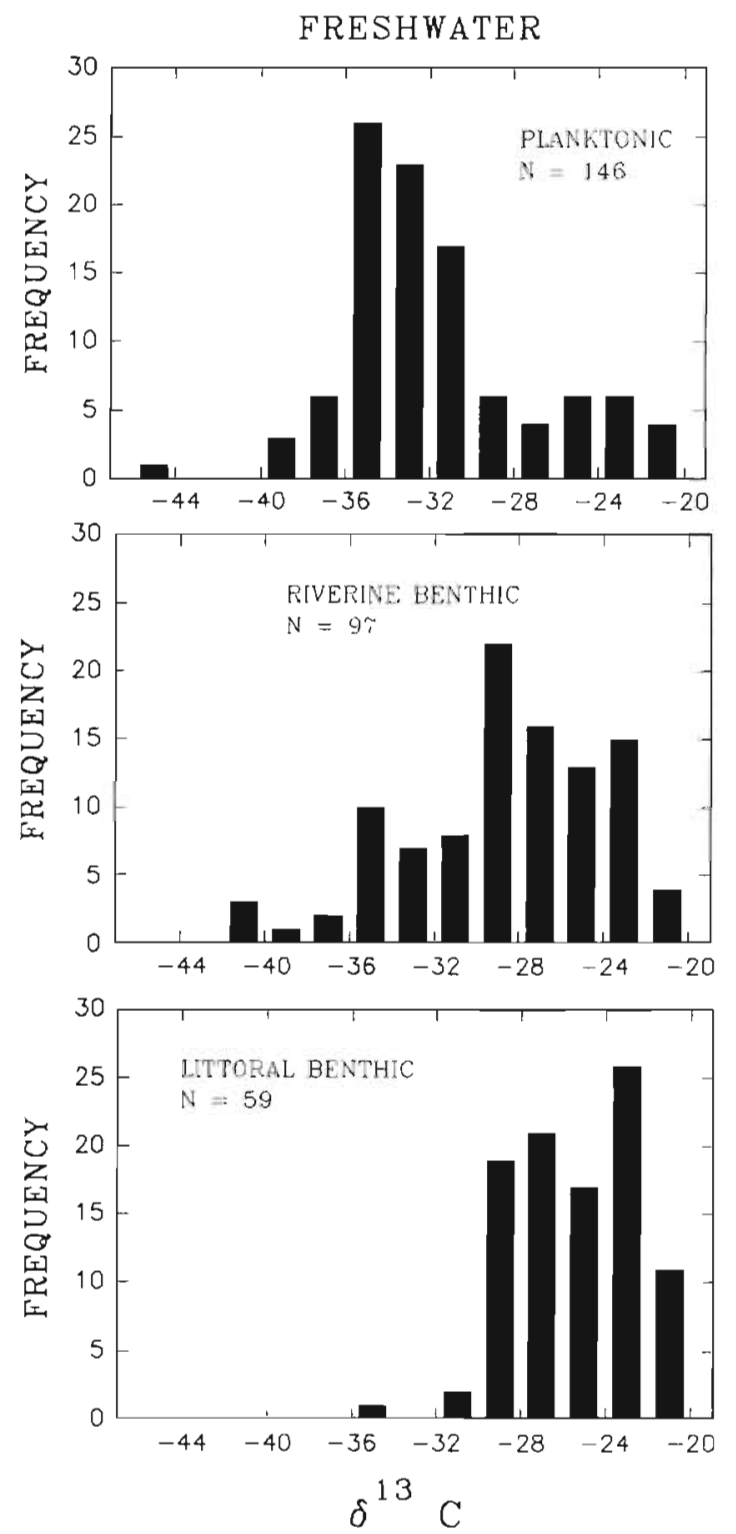

Fig. 2. Percentage frequency distributions of stable carbon isotope ratios for benthic algae in lake littoral zones and rivers and for planktonic algae in lake pelagic zones

ual study basis (Fig. 3), the $\delta^{13} \mathrm{C}$ difference between benthic and planktonic algae ranged from 1 to $10 \%$ (mean $=6 \%$ ) for marine coastal areas, and from 3 to $12 \%($ mean $=7 \%$ ) for lakes.

Algal $\delta^{13} \mathrm{C}$ therefore displays the same relationship to water movement as found previously for angiosperm macrophytes (Osmond et al. 1981) and suggested for marine macroalgae (Simenstad et al. 1993). The boundary layer which develops over benthic algae in littoral zones may be a key factor in regulating benthic community metabolism through internal recycling of both nutrients (Conover 1968, Riber \& Wetzel 1987) and carbon (this data compilation). Because the boundary layers for benthic algae are reduced in thickness with faster water movement (Jørgensen \& Revsbech 1985), the exchange with the bulk solution of both nutrients (e.g. Lock \& John 1979, Riber \& Wetzel 1987, Stevenson \& Glover 1993) and carbon (this study) increases in such situations. Moreover, the even greater water turbulence to which planktonic algae are exposed functions to maintain still lower diffusion resistances, thereby supplying the cells with fresh carbon at higher rates and promoting even greater ${ }^{13} \mathrm{C}$-depletion.

A notable distinction was found to exist between the $\delta^{13} \mathrm{C}$ values of benthic, seagrass-dominated foodwebs (which are based on algae, not vascular plants; France 1995a) and pelagic, planktonic foodwebs (Fig. 4). Separation between these 2 foodwebs was more evident for the generally sessile invertebrates than it was for the mobile fishes. Seagrass invertebrates exhibited a unimodal distribution in $\delta^{13} \mathrm{C}$ with a considerable range from -24 to $-5 \%$, centered about a mode of $-14 \%$. By comparison, the range in $\delta^{13} \mathrm{C}$ displayed by offshore invertebrates was much reduced (-24 to $-14 \%$ ), centered about a mode of $-20 \%$. Offshore fishes ranged in $\delta^{13} \mathrm{C}$ from -20 to $-11 \%$, centered about a mode of $-17 \%$. Seagrass fishes showed a greater range in $\delta^{13} \mathrm{C}$ from -20 to $-8 \%$, and displayed a bimodal frequency distribution with modes at -18 and $-13 \%$. Obviously, a substantial proportion of the fishes collected from seagrass meadows ultimately derive their carbon from the plankton-based, rather than the benthic-based, foodweb. Similarly, compilation of $\delta^{13} \mathrm{C}$ data for such non-seagrass, non-estuarine

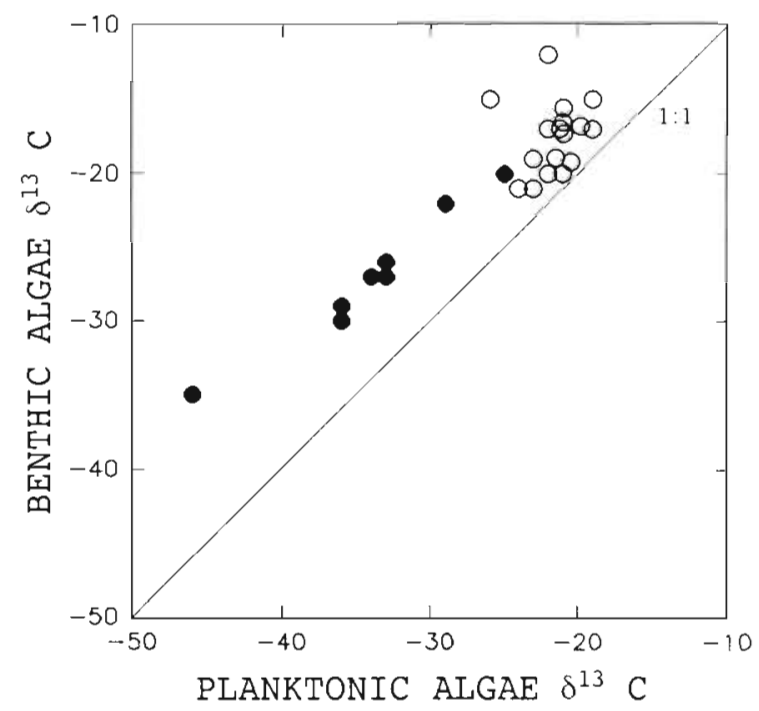

Fig. 3. Study-specific differences in stable carbon isotopes between benthic and planktonic algae for (0) freshwater and (O) marine environments 

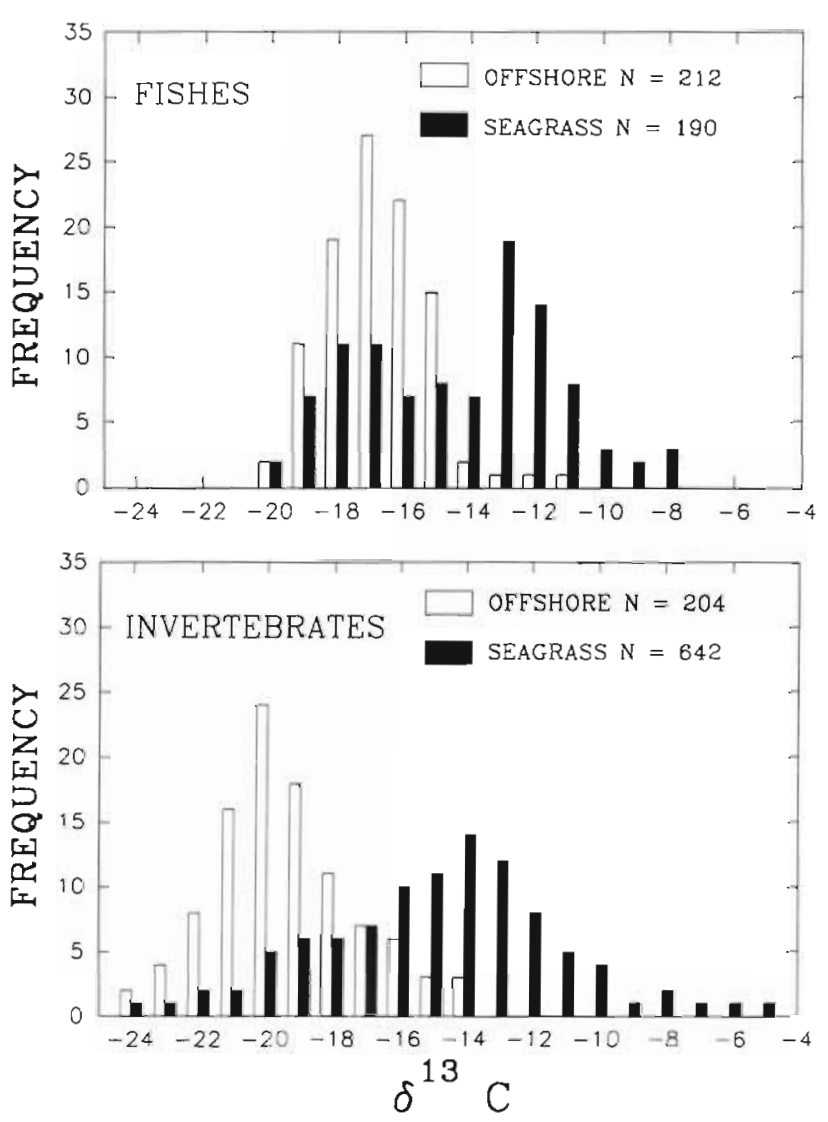

Fig. 4. Percentage frequency distributions of stable carbon isotope ratios for consumers collected from seagrass meadows and offshore coastal regions around the world. Data sources available upon request

systems as rocky shores, kelp beds, coral reefs, mangrove swamps and many other coastal regions worldwide, indicated that the same separation between benthic and planktonic foodwebs existed in these habitat types as well (Fig. 5).

In summary, the ${ }^{13} \mathrm{C}$-enrichment of benthic compared to planktonic algae, as a possible consequence of reduced water turbulence, is substantial enough to be reflected in the isotopic values of benthic consumers. Coastal fauna utilizing benthic carbon sources are on average enriched in ${ }^{13} \mathrm{C}$ by about $5 \%$ compared to animals deriving their carbon from phytoplankton. Carbon isotope analysis can, therefore, be used as a rapid procedure for distinguishing between benthic and planktonic food sources for coastal animals (e.g. Hobson 1993, Hobson et al. 1994). For example, seagrass fishes having $\delta^{13} \mathrm{C}$ values more negative than $-15 \%$ are probably components of the planktonic foodweb, while those displaying $\delta^{13} \mathrm{C}$ values more positive than $-14 \%$ almost certainly derive their carbon from benthic algae. Seagrass invertebrates exhibiting $\delta^{13} \mathrm{C}$ values less than $-18 \%$ are probably dependent

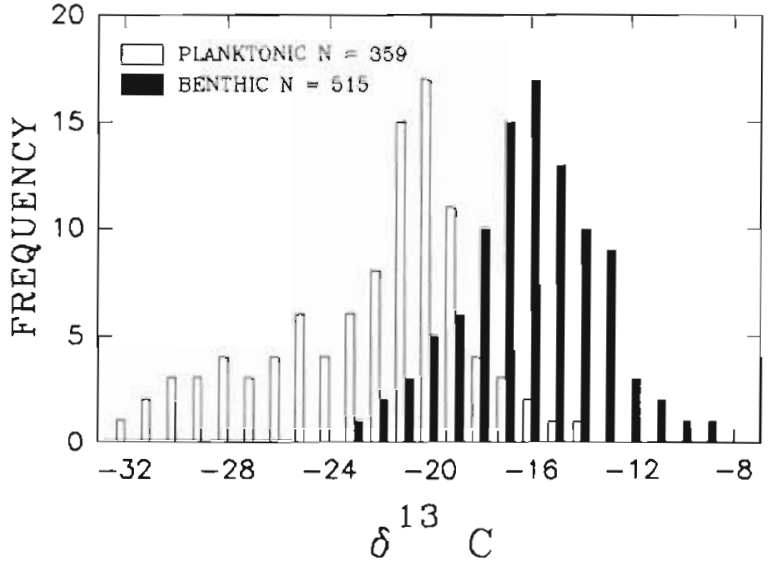

Fig. 5. Percentage frequency distributions of stable carbon isotope ratios for consumers collected from non-seagrass, non-estuarine coastal regions around the world. Data sources available upon request

upon phytoplankton, whereas those having $\delta^{13} \mathrm{C}$ values greater than $-16 \%$ are most likely components of a benthic foodweb. Other coastal consumers in nonseagrass regions that rely upon phytoplankton for sustenance will generally display $\delta^{13} \mathrm{C}$ values below $-20 \%$, whereas those individuals dependent upon benthic algae most commonly will have $\delta^{13} \mathrm{C}$ signatures enriched above $-19 \%$.

The present demonstration of different carbon isotopic signatures for benthic and planktonic algal food sources as the likely reason for the relative ${ }^{13} \mathrm{C}$ enrichment of benthic consumers provides a counter hypothesis to that of Fry \& Sherr (1984), who supposed that the ${ }^{13} \mathrm{C}$-enrichment present in continental shelf foodwebs may be caused by an increased number of trophic levels and, therefore, further isotopic fractionation steps. Finally, it has recently been shown that such a discrimination between planktonic and benthic foodwebs, as a result of observed differences between the carbon isotopic ratios of attached algae and phytoplankton, also exists in freshwaters as well (France 1995b).

Acknowledgements. This study was funded by a Canadian NSERC Strategic Grant for work on ecotonal coupling in lake littoral zones. Conversations about carbon isotopic variability with R. Peters, G. Cabana, P. del Giorgio, J. Blais, and especially $R$. Hesslein were beneficial to the ideas contained herein. R. Peters is thanked for reviewing the manuscript.

\section{LITERATURE CITED}

Andrews JJ, Abel KM (1979) Photosynthetic carbon metabolism in seagrasses. Plant Physiol 63:650-656

Araujo-Lima C, Forsberg BR, Victona R, Martinelli L (1986) Energy sources for detritivorous fishes in the Amazon. 
Science 234:1256-1258

Bunn SE, Barton DR, Hynes HBN, Power G, Pope MA (1989) Stable isotope analysis of carbon flow in a tundra river system. Can J Fish Aquat Sci 46:1769-1775

Bunn SE, Boon PI (1993) What sources of organic carbon drive food webs in billabongs? A study based on stable isotope analysis. Oecologia 96:85-94

Conover JT (1968) The importance of natural diffusion gradients and transport of substances related to benthic marine plant metabolism. Botanica mar 11:1-9

Degens ET, Behrendt M, Gotthardt B, Reppmann E (1968b) Metabolic fractionation of carbon isotopes in marine plankton. II. Data on samples collected off the coasts of Peru and Ecuador. Deep Sea Res 15:11-20

Degens ET, Guillard R, Sackett WM, Hellebust JA (1968a) Metabolic fractionation of carbon isotopes in marine plankton. I. Temperature and respiration experiments. Deep Sea Res 15:1-9

Deuser WG (1970) Isotopic evidence for diminishing supply of available carbon during diatom bloom in the Black Sea. Nature 225:1069-1071

Estep ML, Vigg S (1985) Stable carbon and nitrogen isotope tracers of trophic dynamics in natural populations and fisheries of the Lahontan Lake system, Nevada. Can J Fish Aquat Sci 42:1712-1719

Fageneli J, Vukovic A, Saleh FI, Pezdic J (1986) C:N:P ratios and stable carbon and hydrogen isotopes in the benthic marine algae, Ulvarigida C. Ag. and Fucus virsoides J. Ag. J exp mar Biol Ecol 102:153-166

Fontugne M, Duplessy JC (1978) Carbon isotope ratios of marine plankton related to surface water masses. Earth planet Sci Lett 41:365-371

Forsberg BR, Araujo-Lima C, Martinelli LA, Victoria RL, Bonassi JA (1993) Autotrophic carbon sources for fish of the central Amazon. Ecology 74:643-652

France RL (1995a) Stable isotope survey of the role of macrophytes in the carbon flow of aquatic foodwebs. Vegetatio (in press)

France RL (1995b) Differentiation between littoral and pelagic foodwebs in lakes using stable carbon isotopes. Limnol Oceanogr (in press)

Fry B (1991) Stable isotope diagrams of freshwater food webs. Ecology 72:2293-2297

Fry B, Lutes R, Northam M, Parker PL $(1982)$ A ${ }^{13} \mathrm{C} /{ }^{12} \mathrm{C}$ comparison of food webs in Caribbean seagrass meadows and coral reefs. Aquat Bot 14:389-398

Fry B, Scalan RS, Parker PL $[1983){ }^{13} \mathrm{C} /{ }^{12} \mathrm{C}$ ratios in marine food webs of the Torres Strait, Queensland. Aust J mar Freshwat Res 54:707-716

Fry B, Sherr EB (1984) $\delta^{13} \mathrm{C}$ measurements as indicators of carbon flow in marine and freshwater ecosystems. Contr mar Sci $27: 15-47$

Fry B, Wainright SC (1991) Diatom sources of ${ }^{13} \mathrm{C}$-rich carbon in marine food webs. Mar Ecol Prog Ser 76:149-157

Gearing JN, Gearing PJ, Rudnick DT, Requejo AG, Hutchins MJ (1984) Isotopic variability of organic carbon in a phytoplankton-based estuary. Geochim Cosmochim Acta 48: $1089-1098$

Haines EB (1976) Stable carbon isotope ratios in the biota. soils and tidal water of a Georgia salt marsh. Estuar coast mar Sci 4:609-616

Haines EB, Monague CL (1979) Food sources of estuarine invertebrates analyzed using ${ }^{13} \mathrm{C} /{ }^{12} \mathrm{C}$ ratios. Ecology 60:48-56

Hamilton SK, Lewis WM. Sippel SJ (1992) Energy sources for aquatic animals in the Orinoco River floodplain: evidence from stable isotopes. Oecologia 89:324-330

Hesslein RH, Cape] MJ, Fox DE, Hallard KA (1991) Stable isotopes of sulfur, carbon, and nitrogen as indicators of trophic level and fish migration in the lower Mackenzie River Basin, Canada. Can J Fish Aquat Sci 48:2258-2265

Hobson KA (1993) Trohpic relationships among high Arctic seaburds: insights from tissue-dependent stable-isotope models. Mar Ecol Prog Ser 95:7-18

Hobson KA, Piatt JF, Pitocchelli J (1994) Using stable isotopes to dtermine seabird trophic relationships. J Anim Ecol 63:786-798

Hobson KA, Welch HE (1992) Determination of trophic relationships within a high Arctic marine food web using $\delta^{13} \mathrm{C}$ and $\delta^{15} \mathrm{~N}$ analysis. Mar Ecol Prog Ser 84:9-18

Hughes EH, Sherr EB (1983) Subtidal food webs in a Georgian estuary: $\delta^{13} \mathrm{C}$ analysis. J exp mar Biol Ecol 67:227-242

Jørgensen BB, Revsbech NP (1985) Diffusive boundary layers and the oxygen uptake of sediments and detritus. Limnol Oceanogr 30:111-122

Junger M, Planas D (1993) Alteration of trophic interactions between periphyton and invertebrates in an acidified stream: a stable carbon isotope study. Hydrobiologia 262. $97-107$

Keeley JE, Sandquist DR (1992) Carbon: freshwater plants Plant Cell Environ 15:1021-1035

Kline TC, Goering JJ, Mathisen OA, Poe AL, Parker PL (1990) Recycling of elements transported upstream by runs of Pacific salmon: I. $\delta^{15} \mathrm{~N}$ and $\delta^{13} \mathrm{C}$ evidence in Sashin Creek, southeastern Alaska. Can J Fish Aquat Sci 47:136-144

Kling GW (1994) Ecosystem-scale experiments. The use of stable isotopes in fresh waters. In: Baker LA (ed) Environmental chemistry of lakes and reservoirs. Adv in Chem, Ser 237. Am Chem Soc, Washington, DC, p 91-120

LaZerte BD (1983) Stable carbon isotope ratios: implications for the source of sediment carbon and for phytoplankton carbon assimilation in Lake Memphremagog, Quebec Can J Fish Aquat Sci 40:1658-1666

Lock MA, John PH (1979) The effect of flow patterns on the uptake of phosphorus by river periphyton. Limnol Oceanogr 24:376-383

Macko SA, Lee WY, Parker PL (1982) Nitrogen and carbon isotope fractionation by two species of marine amphipods: laboratory and field studies. J exp mar Biol Ecol 63: $145-149$

McConnaughey T, McRoy CP (1982) Food-web structure and the fractionation of carbon isotopes in the Bering Sea. Mar Biol 53:257-262

Mihuc T, Toetz D (1994) Determination of diets of alpine insects using stable isotopes and gut analysis. Am Midl Nat 131:146-155

Nichols PD, Klumpp DW, Johns RB (1985) A study of food chains in seagrass communities. III. Stable isotope ratios. Aust J mar Freshwat Res 36:683-690

Osmond CB, Valaane N, Haslam SM, Votila P, Roksandic Z (1981) Comparisons of $\delta^{13} \mathrm{C}$ values in leaves of aquatic macrophytes from different habitats in Britain and Finland: some implications for photosynthesis processes in aquatic plants. Oecologia 50:117-124

Parker PL (1964) The biogeochemistry of the stable isotopes of carbon in a marine bay. Geochim Cosmochim Acta 28: $1155-1164$

Peterson BJ, Howarth RW (1987) Sulfur, carbon, and nitrogen isotopes used to trace organic matter flow in the salt-marsh estuaries of Sapelo Island, Georgia. Limnol Oceanogr 32 : $1195-1213$

Rau GH (1980) Carbon-13/carbon-12 variation in subalpine lake aquatic insects: food source implications. Can J Fish Aquat Sci 37:742-746

Rau GH, Teyssie JL, Rassoulzadegan F, Fowler SW (1990) 
${ }^{13} \mathrm{C} /{ }^{12} \mathrm{C}$ and ${ }^{15} \mathrm{~N} /{ }^{14} \mathrm{~N}$ variations among size-fractionated marine particles: implications for their origin and trophic relationships. Mar Ecol Prog Ser 59:33-38

Raven JA (1970) Exogenous inorganic carbon sources in photosynthesis. Biol Rev 45:167-228

Riber HH, Wetzel RG (1987) Boundary-layer and internal diffusion effects on phosphorus fluxes in lake periphyton. Limnol Oceanogr 32:1181-11.94

Rodelli MR, Gearing JN, Gearing PJ, Marshall N, Sasekumar A (1984) Stable isotope ratio as a tracer of mangrove carbon in Malaysian ecosystems. Oecologia 61:326-333

Rosenfield JS, Roff JC (1992) Examination of the carbon base in southern Ontario streams using stable isotopes. J $\mathrm{N}$ Am Benthol Soc i 1:1-10

Rounick JS, Hicks BJ (1985) The stable carbon isotope ratios of fish and their invertebrate prey in four New Zealand rivers. Freshwat Biol 15:207-214

Rounick JS, Winterbourn MJ, Lyon GL (1982) Differential utilization of allochthonous and autochthonous inputs by aquatic invertebrates in some New Zealand streams: a stable isotope study. Oikos 39:191-198

Sackett WM, Eckelmann WR, Bender ML, Be AW (1.965) Temperature dependence of carbon isotope composition in marine plankton and sediments. Science 148:235-237

Schwinghamer P. Tan FC, Gordon DC (1983) Stable carbon isotope studies on the Pecks Cove mudflat ecosystem in the Cumberland Basin, Bay of Fundy. Can J Fish Aquat Sci 40(Suppl 1):262-272

Shoto-Douglas AD, Field JG, James AG, van der Merwe NJ (1991) ${ }^{13} \mathrm{C} /{ }^{12} \mathrm{C}$ and ${ }^{15} \mathrm{~N} /{ }^{14} \mathrm{~N}$ isotope ratio undicators in the Southern Benguela ecosystem: indicators of food web relationships among different size-classes of plankton and pelagic fish; differences between fish muscle and bone collagen tissies. Mar Ecol Prog Ser 78:23-31

Simenstad CA, Duggins DO, Quay PD (1993) High turnover of inorganic carbon in kelp habitats as a source of $\delta^{1.3} \mathrm{C}$ variability in marine food webs. Mar Biol 116:147-160

Simenstad CA, Wissmar RC (1985) $\delta^{13} \mathrm{C}$ evidence of the origins and fates of organic carbon in estuarine and near-

This note was submitted to the editor shore food webs. Mar Erol Prog Ser 22:141-152

Smith FR, Walker NA (1980) Photosynthesis by aquatic plants: effects of unstirred layers in relation to assimlation of $\mathrm{CO}_{2}$ and $\mathrm{HCO}_{3}$ and to carbon isotoplc discrimination. New Phytol 86:245-259

Stevenson RJ, Glover R (1993) Effects of algal density and current on ion transport through periphyton communities. Limnol Oceanogr 38:1276-1281

Sullivan MJ, Moncreiff CA (1990) Edaphic algae are an important component of salt-marsh food-webs: evidence from multiple stable isotope analyses. Mar Ecol Prog Ser 62:149-159

Takahashi K, Wada K, Sakamoto M (1990a) Carbon isotope discrimination by phytoplankton and photosynthetic bacteria in monomictic Lake Fukami-ike. Arch Hydrobiol 120 : $197-210$

Takahashi K, Yoshioka T, Wada E, Sakamoto M (1990b) Temporal variations in carbon isotope ratio of phytoplankton in a eutrophic lake. J Plankton Res 12:799-808

Wada E, Terasakj M, Kabcya Y, Nemoto T (1987) $\delta^{1 \mathrm{~N}} \mathrm{~N}$ and $\delta^{13} \mathrm{C}$ abundances in the Antarctic Ocean with emphasis on the biogeochemical structure of the food web. Deep Sea Res 34:829-841

Wheeler WN (1980) Effect of boundary layer transport on the fixation of carbon by the giant kelp Macrocystis pyrifera. Mar Biol 56:103-110

Wienke C, Fisher G (1990) Growth and stable carbon isotope composition of cold-water macroalgae in relation to light and temperature. Mar Ecol Prog Ser 65:283-292

Winterbourn MJ, Rounick is, Hildrew AG (1986) Patterns of carbon resource utilization by benthic invertebrates in two British river systems: a stable carbon isotope study. Arch Hydrobiol 107:349-361

Yoshioka T, Hayashi H, Wada E (1989) Seasonal variations of carbon and nitrogen isotope ratios of plankton and sinking particles in Lake Kizaki. Jap J Limnol 50:3123-320

Yoshioka T, Wada E, Saijo Y (1988) Analysis of lacustrine food web with natural carbon and nitrogen isotope ratios. Verh int Verein Limnol 23:573-578

Manuscript first received: July 5, 1994

Revised version accepted: March 2, 1995 